INTERNATIONAL RESEARCH JOURNAL OF PHARMACY

www.irjponline.com

ISSN $2230-8407$

Research Article

\title{
PHYTOCHEMICAL STUDY, ANTIOXIDANT AND ANTIMICROBIAL ACTIVITIES OF EUPHORBIA RESINIFERA L.
}

Houcine Benmehdi ${ }^{1,2 *}$, Nadia Bounoua ${ }^{1}$, Abdelillah Amrouche ${ }^{3}$, Driss Lahcene ${ }^{1}$, Abdelhak Maazouzi ${ }^{4}$

${ }^{1}$ Faculty of Sciences and Technology, Department of Technology, University of Bechar, Algeria

${ }^{2}$ Laboratory of LASNABIO, Department of Chemistry, University of Tlemcen, Algeria

${ }^{3}$ Faculty of Sciences and Technology, Department of Sciences, University of Bechar, Algeria

${ }^{4}$ Laboratory of Energetic of arid areas ENERGARID, University of Bechar, Algeria

*Corresponding Author Email: h_ben90@yahoo.fr

Article Received on: 12/08/13 Revised on: 07/09/13 Approved for publication: 19/09/13

DOI: 10.7897/2230-8407.04910

IRJP is an official publication of Moksha Publishing House. Website: www.mokshaph.com

(C) All rights reserved.

\begin{abstract}
The present study was aimed at detecting the phytochemicals and evaluating the antioxidant and antimicrobial activities of Euphorbia resinifera known for their medicinal properties in folk medicine. Phytochemical screening was carried out on the aerial part of Euphorbia resinifera. The assessment of antifungal activity was performed in terms of percentage of radial growth on solid medium (potatoes dextrose agar PDA) against Aspergillus flavus and Penicillium expansum. The antibacterial effect was studied by the agar direct contact method using Staphylococcus aureus, Pseudomonas aeruginosa and Escherichia coli strains. Then, the antioxidant evaluation of the extracts of alkaloids, flavonoids and methanolic extract was performed by DPPH ${ }^{\bullet}$ free radical scavenging and high performance thin layer chromatography (HPTLC) techniques. The phytochemical estimation revealed the presence of alkaloids, flavonoids and saponosides. These phytochemicals were isolated from the plant with yields of $0.7 \%, 0.4 \%$ and $0.35 \%$. HPTLC screening provided qualitatively the antioxidant effect of extracts under study. Furthermore, it was found that the methanolic, flavonoids and alkaloids extracts had a potent DPPH scavenging potency with $\mathrm{IC}_{50}$ values of $0.0086 ; 0.378$ and $1.171 \mathrm{mg} / \mathrm{mL}$, respectively. Finally, the results of antimicrobial activity of the aqueous extract showed a pronounced antifungal activity against the tested strains. The percentage inhibition values were found to be in the range of 64.14 to $85.51 \%$ against Aspergillus flavus and 60.33 to $92.28 \%$ against Penicillium expansum. In contrast, the same extract inhibited only the growth of Escherichia coli bacteria. Further study is recommended to isolate and elucidate the active compounds and to evaluate in vivo their antioxidant and antimicrobial effect.

Keywords: Phytochemicals, extracts, Antioxidant activity, Antimicrobial activity, Euphorbia resinifera $\mathrm{L}$.
\end{abstract}

\section{INTRODUCTION}

Nowadays there is a growing demand in natural agents exhibiting antioxidant properties that are supplied to human and animal organisms as food components or as pharmaceutical drugs. The plants have been considered as a major source of natural antioxidants and antimicrobials. However, there is little knowledge about the practical usefulness of most of them. In the variety of secondary plant metabolites, antioxidant phenolic acids, flavonoids and alkaloids are commonly found in various plant organs and they have been shown to provide a defence against cancer and oxidative stress from oxidizing agents and free radicals ${ }^{1-}$ 5 . For thousands of years, natural products have been used as antibiotics and other modern drugs to treat several health problems. The investigation of certain plants for their antimicrobial and antioxidant properties may yield useful results. It has been reported that $10 \%$ of the flowering plants were used by patients to treat various infection, although only $1 \%$ have gained recognition by modern scientists. ${ }^{6}$ The acceptance of folk medicine as an alternative form for health care and the development of microbial resistance to the available antibiotics has led searchers worldwide to investigate the antimicrobial potency of medicinal plants. ${ }^{7}$ Generally, a number of secondary metabolites have been reported from various plants including tannins, alkaloids and flavonoids which showed a large antimicrobial spectrum. ${ }^{8}$ Euphorbia resinifera L. is one of 2000 species of Euphorbiaceae family. It is a dense succulent shrub growing to $60 \mathrm{~cm}$ tall, forming multi stemmed cushion-shaped clumps up to $2 \mathrm{~m}$ wide. Lime to blue green with short brown spines, small leaves that drop early and are rarely seen, new growth takes on a reddish colour. It is four-sided almost square stems that look superficially like a cactus. Besides, it can take more light and frost than other Euphorbia. ${ }^{9}$ It is native to Morocco, where it occurs on the slopes of the Atlas Mountains in the surroundings of Marrakesh. ${ }^{10}$ In Algeria, it is widespread throughout the mountains of Naama (SouthWest of Algeria). Euphorbia resinifera L. has been reported to have anticancer activity. In Morocco folk medicine, the patients treat the general cancer by the grind aerial parts of Euphorbia resinifera mixed with honey. ${ }^{11}$ Ethno pharmacological survey carried out in different areas of Algeria Naama department (Mecheria, ain sefra, Djenien Bou Rezg, Tiout and Ain Ben khelil) and performed by means of 150 interviews, revealed that Euphorbia resinifera L. is used to treat many diseases such us cancer, rheumatism, cyst and snake bite poisoning). Chemically, Euphorbia resinifera is known to contain a high concentration of the toxin resinifera toxin which is being an ultra potent capsaicin analogue present in the latex, interacts at a specific membrane recognition site, expressed by primary sensory neurons mediating pain perception as well as neurogenic inflammation. ${ }^{12,13}$ According to the literature data, antimicrobial activity of crude aqueous extract and antioxidant power of the alkaloids, flavonoids and methanol crude extracts have not been reported. In search of finding new resources and potent antimicrobial and antioxidant, the present study aimed to: 1) carry out a phytochemical study of Euphorbia resinifera L.; 2) evaluate the antioxidant power of the alkaloids, flavonoids and methanol crude extracts; 3 ) to investigate the antibacterial and antifungal activity of aqueous extract of Euphorbia resinifera L. against bacteria and fungi strains. 


\section{MATERIALS AND METHODS}

\section{Plant Material}

The plant Euphorbia resinifera L. was collected in February 2012 from Naama department, Algeria. A voucher specimen of the plant was identified and authenticated at the laboratory of botany at the biology Institute. The plant was shad dried and ground by an electrical mill mesh and powdered material was defatted with hexane according to the method of Villarreal-Lozoya et al. ${ }^{14}$ Then, sample was stored in nylon bag in a deep freeze until the time of use.

\section{Preparation of the Extracts}

Preparation of Methanol, Diethylether and Aqueous Extracts

About $20 \mathrm{~g}$ each of the powdered plant were macerated three times with $60 \mathrm{~mL}$ of diethyl ether for ten minutes. The extracts were filtered using Whatman filter paper and concentrated to $25 \mathrm{~mL}$. The filtrates were labelled appropriately as diethyl ether extract. The marc of each part was then macerated in methanol using the same above protocol. The obtained extracts were labelled as methanol extract. Another $5 \mathrm{~g}$ of each plant material was extracted by infusion in $50 \mathrm{~mL}$ of distilled water. After shaking for 15 minutes, the extract was filtered through Whatman's filter paper and labelled as aqueous extract. The three extracts were used for the phytochemical screening. ${ }^{15}$

\section{Preparation of the Flavonoids Extract}

A mixture of defatted powder of plant $(100 \mathrm{~g})$ in $100 \mathrm{~mL}$ of distilled water and $100 \mathrm{~mL}$ of acetone was refluxed for $12 \mathrm{~h}$. After filtration of the marc and evaporation of acetone, the remaining aqueous extract was extracted twice with $50 \mathrm{ml}$ of petroleum ether in order to remove chlorophyll and lipophilic compounds. Then, aqueous layer was extracted thrice with 50 $\mathrm{mL}$ of ethyl acetate. The organic layer was then dried over $\mathrm{Na}_{2} \mathrm{SO}_{4}$, filtered and concentrated to dryness to give crude extract of flavonoids as a brownish solid. ${ }^{16}$

\section{Preparation of the Alkaloids Extract}

Defatted dry powdered plant $(100 \mathrm{~g})$ was alkalized with 40 $\mathrm{ml}$ of ammoniac $(0.5 \mathrm{~N})$ for $8 \mathrm{~h}$ at room temperature. The alkalized powder was extracted with dichloromethane (250 $\mathrm{mL}$ ) in a Soxhlet apparatus for $4 \mathrm{~h}$. The dichloromethane extract was subjected to sulphuric acid $(0.5 \mathrm{~N})$ extractions $(3$ $\mathrm{x} 150 \mathrm{~mL}$ ), and then the aqueous layer was adjusted to $\mathrm{pH}=$ 9 with concentrated ammoniac. The aqueous basic solution was extracted with chloroform several times. The combined chloroform extract was dried over sodium sulphate and evaporated to give the crude alkaloid mixture. ${ }^{17}$

\section{Preparation of the Saponosides Extract}

About $100 \mathrm{~g}$ powdered plant were dispersed in $200 \mathrm{~mL}$ of 20 $\%$ ethanol. The suspension was heated over a hot water bath for $4 \mathrm{~h}$ with continuous stirring at about $55^{\circ} \mathrm{C}$. The mixture was filtered and the residue re-extracted with another $200 \mathrm{~mL}$ of $20 \%$ ethanol. The combined extracts were reduced to 40 $\mathrm{mL}$ over water bath at about $90^{\circ} \mathrm{C}$. The concentrate was transferred into a $250 \mathrm{~mL}$ separator funnel and $20 \mathrm{~mL}$ of diethyl ether was added and shaken vigorously. The aqueous layer was recovered while the ether layer was discarded. The purification process was repeated. About $60 \mathrm{~mL}$ of n-butanol was added. The combined n-butanol extracts were washed twice with $10 \mathrm{~mL}$ of $5 \%$ aqueous sodium chloride. The remaining solution was heated in a water bath. After evaporation, the samples were dried in the oven to a constant weight. The saponin content as a yellow solid was calculated in percentage. ${ }^{18}$

\section{Preparation of the Methanolic Crude Extract}

About $20 \mathrm{~g}$ of powdered material was macerated with $80 \mathrm{~mL}$ of methanol for $24 \mathrm{~h}$. The methanol extract was filtered using whattman filter paper and then concentrated under vacuum at $40^{\circ} \mathrm{C}$ using a rotary evaporator. Finally, crude extract was obtained. The crude extract was stored at $4^{\circ} \mathrm{C}$ prior to antioxidant tests.

\section{Phytochemical Screening}

The diethyl ether, methanol and water extracts were screened for phytochemical constituents (flavonoids, alkaloids, saponins, sterols, terpenoids, tannins, anthraquinones, anthracenosides, anthocyanosides, coumarins, reducing sugars, fatty acids and volatile oils) using standard procedures to identify the constituents as described by Sofowora ${ }^{19}$ and Harborne. ${ }^{20}$

\section{Antioxidant activity \\ Determination of free radical scavenging activity by DPPH method}

The antioxidant potential of the alkaloids, flavonoids, saponosides and methanolic crude extracts were determined on the basis of their scavenging activity of the stable 1, 1diphenyl-2-picrylhydrazyl (DPPH) free radical. Briefly, 100 $\mu \mathrm{L}$ of various concentrations of the each extract in methanol was added to $1.9 \mathrm{~mL}$ of a methanol solution of DPPH $(0.004$ $\%)$. The mixture was vigorously shaken and then allowed to stand at room temperature for 30 minutes in the dark. The absorbance of the mixture was measured at $517 \mathrm{~nm}$ by using a double-beam UV-vis Camspec M550 spectrophotometer. A mixture of $100 \mu \mathrm{L}$ of methanol and $1.9 \mathrm{~mL}$ of DPPH solution was used as the control. The scavenging activity on the DPPH radical was expressed as inhibition percentage using the following equation:

$$
\% \text { Inhibition }=\left[\left(A_{B}-A_{S}\right) / A_{B}\right] \times 100
$$

Where $A_{B}$ is the absorbance of the control reaction (containing all reagents except the test compound), and $A_{S}$ is the absorbance of the test compound

The commercial known antioxidant, ascorbic acid was used for comparison or as a positive control. ${ }^{21}$ The tests were carried out in triplicate. The extract concentration providing $50 \%$ inhibition $\left(\mathrm{IC}_{50}\right)$ was calculated from the graph of inhibition percentage plotted against extract concentration (0.5; 0.25; 0.125;0.0625;0.0312;0.0156; $0.0078 \mathrm{mg} / \mathrm{mL})$.

High performance thin layer chromatography (HPTLC) study of extracts and DPPH

Alkaloids, flavonoids, saponosides and methanolic crude extracts of Euphorbia resinifera L. were subjected to High performance thin-layer chromatography (HPTLC) on silica gel plate $(20 \times 20 \mathrm{~cm}$, Silica gel F254, Merck). The solvent system optimized for crude extracts of Euphorbia resinifera was methanol and Chloroform (10:90 v/v). Alkaloids, flavonoids, saponosides and methanolic crude extracts were load on TLC silica gel plate and the plate was developed in a sandwich TLC chamber to a distance of $70 \mathrm{~mm}$. After 15 minutes air-drying, the plate was sprayed with $0.004 \%$ (w/v) DPPH reagent prepared in methanol and $10 \%(\mathrm{v} / \mathrm{v})$ sulphuric acid respectively. The spots on the plates were observed after 
the plate has been heated at $60^{\circ} \mathrm{C}$ for 30 minutes exactly after spraying. ${ }^{22}$

\section{Antimicrobial activity \\ Antifungal Activity}

The aqueous extract of Euphorbia resinifera L. was tested by growth radial technique on solid medium. Two fungi strains were used Aspergillus flavus (MTTC 2799) and Penicillium expansum (MTTC 1344). Selected concentrations $\left(\mathrm{v}_{\text {extract }} / \mathrm{v}_{\text {culture medium, }}(\mathrm{mL} / \mathrm{mL}) ;[1 / 15],[2 / 15],[3 / 15],[4 / 15]\right.$ and [5/15]) of Euphorbia resinifera L. aqueous extract were prepared. After agitation, the selected solutions were transferred into a Petri plates which were inoculated with sporal solution (spores of each fungi $+0.2 \%$ agar solution + $5 \%$ tween 80 ) and incubated for 7 days at $25 \pm 2{ }^{\circ} \mathrm{C}$. Mycelial radial growth was measured from the third day of incubation. ${ }^{23,24}$ The inhibition percentage of mycelial growth of each concentration was calculated using the following formula $(\mathrm{PIg}=((\mathrm{DT}-\mathrm{D}) / \mathrm{DT}) \times 100)$ where DT is mean diameter of mycelial growth in control and $\mathrm{D}$ is mean diameter of mycelial growth in treatment. ${ }^{25}$

\section{Antibacterial Activity}

The antibacterial activity was studied by the agar direct contact method. ${ }^{26,27}$ Three bacteria strains were used Staphylococcus aureus (ATCC 25923), Pseudomonas aeruginosa (ATCC 27853) and Escherichia coli (ATCC 25922). Petri dishes (90 cm in diameter) were prepared with $15 \mathrm{ml}$ of a base layer of Müeller-Hinton gelose medium (MHG) and the test organisms were inoculated on nutrient agar plates and spread uniformly using a sterile glass spreader. Various concentrations $\left(\mathrm{v}_{\text {extract }} / \mathrm{v}_{\text {culture medium, }}\right.$ $(\mathrm{mL} / \mathrm{mL}) ;[1 / 15],[2 / 15],[3 / 15],[4 / 15]$ and [5/15]) of the extract were tested. Control experiments comprising inoculums without plant extract were set up. The plates were allowed to stand for one hour at room temperature $\left(25 \pm 2^{\circ} \mathrm{C}\right)$ for diffusion of the substances to proceed before the growth of organisms commenced. The plates were incubated at $37^{\circ} \mathrm{C}$ for $24 \mathrm{~h}$. All tests were performed in triplicate and the antibacterial activity was expressed by the presence or absence of inhibition.

\section{Statistical Analysis}

All values are expressed as Mean \pm standard deviation. The data of inhibition percentage were analyzed using One-way Analysis of Variance (ANOVA). The p-value $<0.05$ was considered as significant.

Table 1: Phytochemicals Detected in Extracts of Euphorbia Resinifera $\mathbf{L}$

\begin{tabular}{|c|c|c|}
\hline Extracts & Phytochemicals & Results \\
\hline \multirow{4}{*}{ Aqueous } & saponins & + \\
\cline { 2 - 3 } & flavonoïds & + \\
\cline { 2 - 3 } & Reducing sugars & - \\
\cline { 2 - 3 } & Starch & + \\
\cline { 2 - 3 } & Anthocyanosides & - \\
\hline Methanolic & Tannins & + \\
\hline Ethanolic & Anthracenosides & + \\
\cline { 2 - 3 } & Alcaloids & + \\
\hline Chloroformic & Anthraquinones & + \\
\cline { 2 - 3 } & Steroles & + \\
\hline \multirow{2}{*}{ Diethyl ether } & Terpenoïds & + \\
\cline { 2 - 3 } & Coumarines & + \\
\cline { 2 - 3 } & Essential oils and fatty acids & + \\
\hline
\end{tabular}

Table 2: Extractions screening of alkaloids, flavonoids and saponosides

\begin{tabular}{|c|c|c|c|}
\hline Phytochemicals & Mass of plant material (g) & Mass of phytochemicals extract (g) & Yield (\%) \\
\hline alkaloids & 100 & 0.70 & 0.70 \\
\hline flavonoids & 100 & 0.3508 & 0.35 \\
\hline saponosides & 100 & 0.412 & 0.41 \\
\hline
\end{tabular}

Table 3- Antifungal screening of aqueous extract against $A$. flavus and $P$. expansum

\begin{tabular}{|c|c|c|}
\hline \multirow{2}{*}{ Concentration (v/v) } & \multicolumn{2}{|c|}{ Percentage of inhibition \pm SD } \\
\cline { 2 - 3 } & A. flavus & P. expansum \\
\hline $1 / 15$ & $64.14 \pm 0.33$ & $60.33 \pm 0.27$ \\
$2 / 15$ & $70.25 \pm 0.29$ & $82.60 \pm 0.18$ \\
$3 / 15$ & $81.97 \pm 0.18$ & $83.34 \pm 0.19$ \\
$4 / 15$ & $82.37 \pm 0.22$ & $88.65 \pm 0.11$ \\
$5 / 15$ & $85.51 \pm 0.14$ & $92.28 \pm 0.08$ \\
\hline
\end{tabular}

Values are Mean \pm SD, the sample was run in triplicate $(n=3), p<0.05$, evaluated by One-way analysis of variance (ANOVA).

Table 4: The antibacterial activity of aqueous extract of $E$. resinifera against some bacterial strains

\begin{tabular}{|c|c|c|c|c|c|}
\hline \multirow{2}{*}{ Bacteria } & \multicolumn{5}{|c|}{ Extract concentrations (V/V) } \\
\cline { 2 - 6 } & $1 / 15$ & $2 / 15$ & $3 / 15$ & $4 / 15$ & $5 / 15$ \\
\hline S. aureus & + & + & + & + & + \\
\hline P. aeruginosa & + & + & + & + & + \\
\hline E. coli & + & - & + & + & - \\
\hline
\end{tabular}

- = no growth of bacteria (inhibition); $+=$ Resistance (growth of bacteria) 


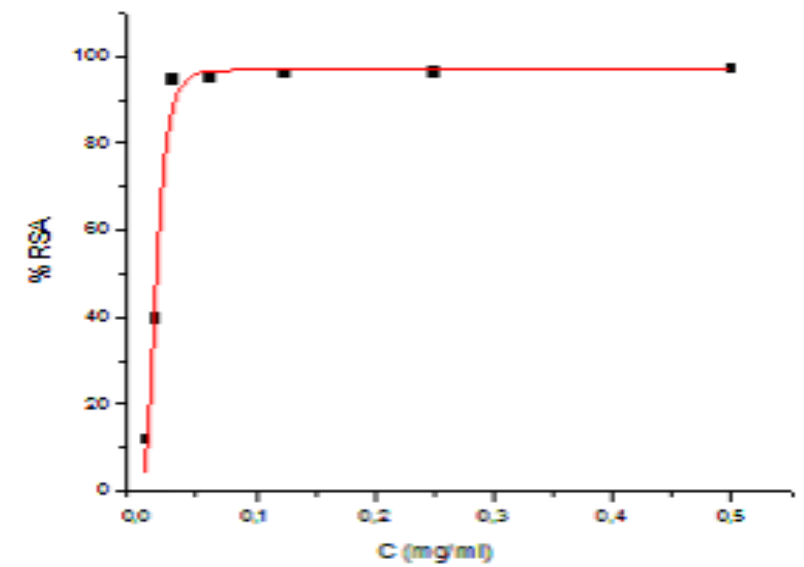

(a)

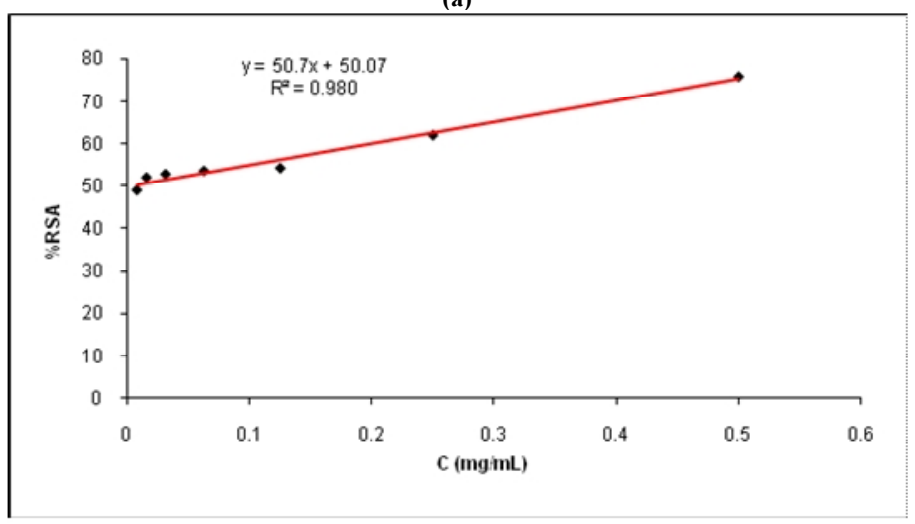

(b)

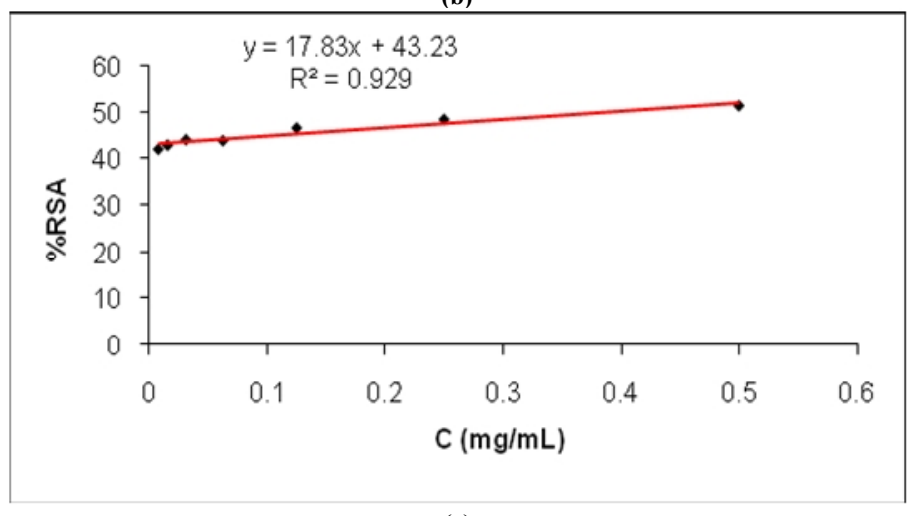

(c)

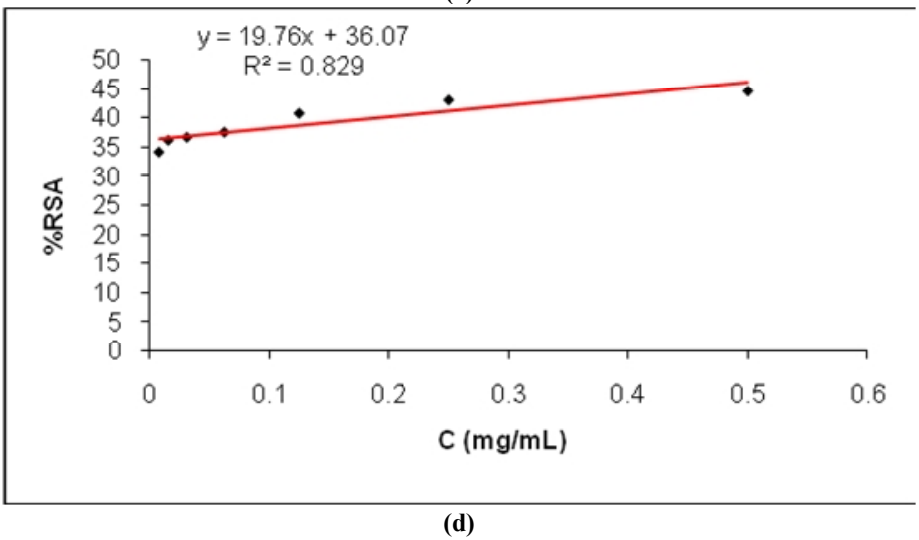

Figure 1: Antioxidant activity of vitamin C (a) and isolated extracts (methanol (b), flavonoids (c) and alkaloids (d)). 


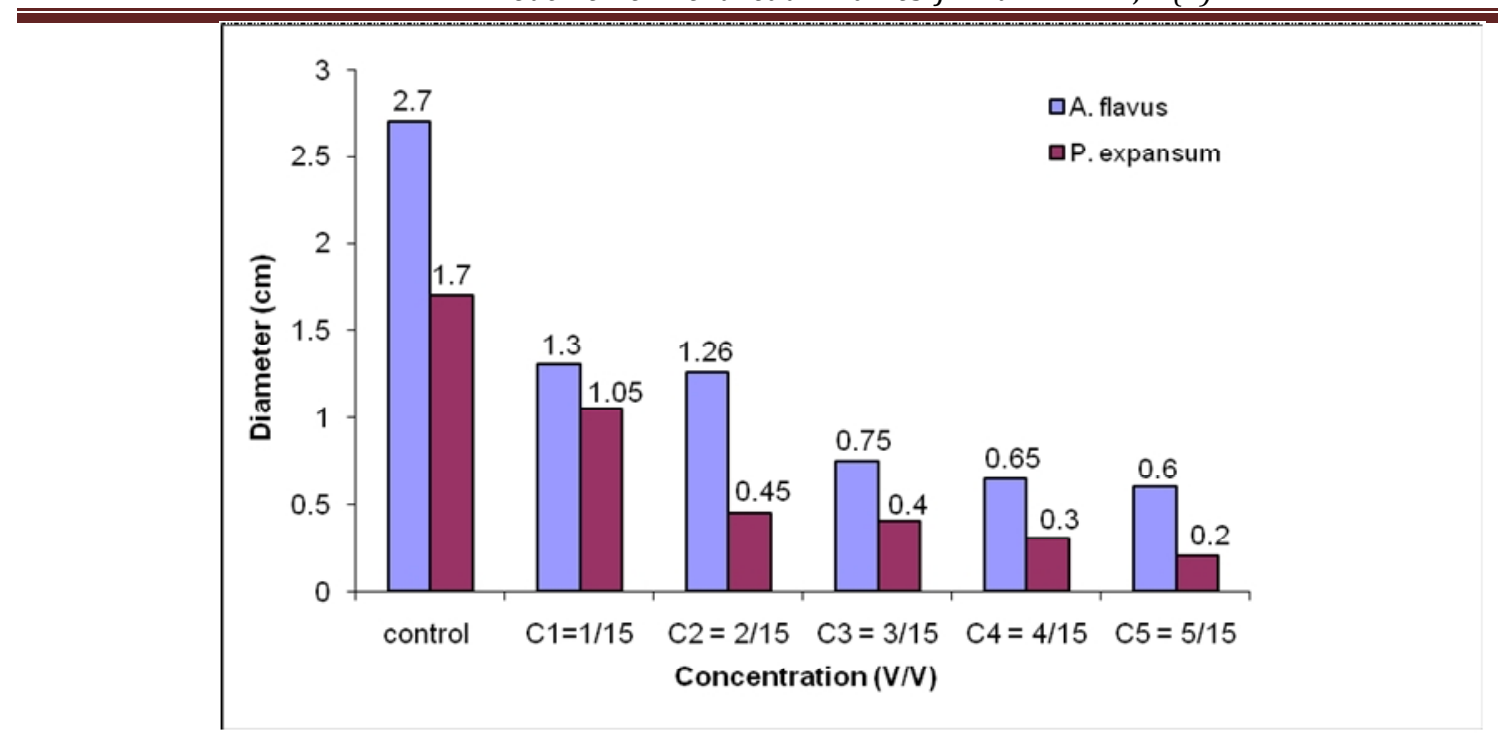

Figure 2: Diameter (cm) of zone inhibition of $E$. Resinifera aqueous extract against $A$. Flavus and $P$. Expansum

\section{RESULTS AND DISCUSSION}

Qualitative phytochemical screening of the aerial part were performed on its diethyl ether, methanolic, ethanolic, chloroformic and water extracts to identify its phytochemicals by using suitable chemicals and reagents (Table 1). In this experience, five solvents with different polarity have been used starting with idea that the solvent polarity is an essential parameter of the solubility of the constituents in the used solvent. The study indicated that alkaloids, saponins, flavonoids, steroles, terpenoids, tannins, anthracenosides, coumarines, reducing sugars, starch, fatty acids and volatile oils were present in the extracts under study. In contrast, the other secondary metabolites like anthraquinones and anthocyanosides were not detected.

Alkaloids, flavonoids and saponosides are the natural compounds which can influence the nutritive value of different food stuffs utilized by human and other animals. These phytoconstituents are known also for their medicinal properties such as antioxidant and antimicrobial activities. ${ }^{28-}$ ${ }^{32}$ In fact, in this part of the present work, these compounds were extracted and the results are given in the Table 2.

The reading of the results revealed that Euphorbia resinifera L. contained alkaloids, flavonoids and saponosides with variable yields. So, from $100 \mathrm{~g}$ of plant material, the content of isolated extracts were observed in this order; alkaloids $(0.70 \mathrm{~g})>(0.41 \mathrm{~g})$ flavonoids $>$ saponosides $(0.35 \mathrm{~g})$. The findings showed clearly that the studied plant contains more alkaloids than flavonoids and saponosides. On the basis of the fact that the phenolic compounds and alkaloids are known for their properties to trap the free radicals ${ }^{33}$, it appeared important to us to make a study of the antioxidant activity of flavonoids, alkaloids and crude methanolic extracts. Using HPTLC bio autography technique, we observe on the TLC plate, the appearance of zones of anti radicalaire activity of yellow colour pale on purple bottom for the extracts under study as for the ascorbic acid. ${ }^{34}$ Purple colour spots were visualized after spraying the plates with sulphuric acid demonstrated the presence of several bioactive compounds in the methanolic crude extract. Furthermore, yellow spots were observed also after spraying the plates with DPPH solution indicating, the presence of antioxidant compounds in the extracts under study. In conclusion, the bio autography
HPTLC method revealed that flavonoids and alkaloids possessed antioxidant effect. Besides, the antioxidant activity observed in the crude methanolic extract probably contributes by phenolic substances it contained. The evaluation of the oxidizing activity with the DPPH by spectrophotometric measurement gave the following results illustrated in Figure 1 (a-d).

The model of scavenging the stable $\mathrm{DPPH}^{\bullet}$ radical is a widely used method to evaluate the free radical scavenging ability of various samples. ${ }^{35}$ DPPH is a stable nitrogencentred free radical, the colour of which changes from violet to yellow upon reduction by either the process of hydrogenor electron- donation. Substances which are able to perform this reaction can be considered as antioxidants and therefore radical scavengers. ${ }^{36}$ The reading of Figure 1a showed a potent antioxidant effect of ascorbic acid with $\mathrm{IC}_{50}$ value of $0.0331 \mathrm{mg} / \mathrm{mL}$. The scavenging reaction carried out in short time and attaints the steady state ( $100 \%$ of inhibition). These results are in agreement with the findings of Hasan et al. (2009) who reported that vitamin C has antioxidant activity evaluated by the DPPH assay. ${ }^{37}$ Regarding antioxidant activity of Euphorbia resinifera crude methanolic extract (Figure 1b), it seems interesting that it showed a higher antioxidant activity compared to acid ascorbique with $\mathrm{IC}_{50}$ value of $0.0086 \mathrm{mg} / \mathrm{ml}$. The antioxidant effectiveness of this extract is mainly attributed to the active compounds present in it such as phenolic compounds, alkaloids and others. Moreover, this effect can be due to the high percentage of main constituents, but also to the presence of other constituents in small quantities or to synergy among them. As shown in fig. $1 \mathrm{~b}$, the scavenging potency of extract increased with the concentration which correlated well with the findings of Popovici et al. ${ }^{38}$ Prabu et al..$^{39}$ and Liu et al. ${ }^{40}$ As seen in Figure 1c, the flavonoids extract exhibited an antioxidant effect better than alkaloids extract and lower than methanolic one. So, the half maximum inhibitory concentration $\mathrm{IC}_{50}$ was estimated to $0.378 \mathrm{mg} / \mathrm{ml}$. The effect of antioxidants on DPPH is thought to be due to their hydrogen donating ability ${ }^{41}$. From the results it showed clearly that the flavonoids extract had an acceptable antioxidant power as ascorbic acid. It's important to underline that our findings are in harmony with several 
reports describing the antioxidant activity of flavonoids. DPPH radical scavenging activity of alkaloids extract of Euphorbia resinifera was presented in Figure 1d. Results showed that the radical scavenging activity of alkaloids extract of Euphorbia resinifera increased with increasing concentration. Isolated alkaloids extract of Euphorbia resinifera shows $\mathrm{IC}_{50} 1.171 \mathrm{mg} / \mathrm{mL}$ and $\mathrm{R}^{2}$ was found to be 0.8294. However Ascorbic acid is used as a standard and its radical scavenging activity was found to be more potent. From the results it seems that alkaloids are the capability to scavenge the free radical DPPH. Several reports confirmed these data. ${ }^{28,46,47}$ On the other hand, The antifungal activity of Euphorbia resinifera specie was tested to prevent the mycelial growth of two fungal organisms Aspergillus flavus and Penicillium expansum that are harmful to human beings and that are known for their production of aflatoxin and ochratoxin. Different concentrations of aqueous extract of aerial parts were tested (Table 3 ). The antifungal activity was determined by measuring the diameter of inhibition zone recorded. As seen in Figure 2, the diameter of inhibition zone is enhanced by increase in the concentration of the Euphorbia resinifera aqueous extract. From the obtained results it showed clearly that the extract under study has a pronounced antifungal activity against Aspergillus flavus and Penicillium expansum.

Using the formula described in material and method section, the percentage of mycelial growth inhibition of aqueous extract at different concentrations are given in Table 3 .

As illustrated in Table 3, the inhibitory plant extract showed capabilities to suppress Aspergillus flavus and Penicillium expansum grown on broth medium. Although, the inhibitory effect of the plant extract increased in proportion to their concentrations. The reading of Table 3 revealed that the aqueous extract of Euphorbia resinifera exhibited a pronounced antifungal activity at all tested concentrations. The findings showed significant percentages of mycelial growth inhibition in the range of 64.14 to $85.51 \%$ against Aspergillus flavus and 60.33 to $92.28 \%$ against Penicillium expansum. The results of the present study authenticated the effective in vitro activity of aqueous extract from Euphorbia resinifera specie and encourage further studies for its application in antibiotic therapy of fungal diseases. The antibacterial activity of Euphorbia resinifera aqueous extract was assayed in vitro by agar diffusion method against Staphylococcus aureus Gram-positive bacteria and Pseudomonas aeruginosa and Escherichia coli gram-negative bacteria. Among the extract concentrations tested, [2/15] and [5/15] showed at least the growth inhibition of Escherichia coli strain; while the remaining concentrations were not active against any of the tested organisms (Table 4). This means that the plant part used and the type of extraction might have resulted in nil activity in the test performed for this study. The differences in potency may be due to locality of the plant specie, time of collection of the plant sample, storage conditions, different sensitivity of the test strains, and method of extraction. ${ }^{48}$

It's important to underline that our results agree with those of Malika et al. who found that honey sample from Euphorbia resinifera has antibacterial activity. ${ }^{49}$ The dilutions of honey ranging from 1/2,1/4,1/8 and 1/16 were tested by the agar well diffusion method on various strains of bacteria including E. coli, Staphylococcus aureus, Bacillus and P. aeruginosa. Results revealed that most of strains were inhibited by the dilution $1 / 2$ and $1 / 4$. The Gram negative strains were found to be more sensitive than Gram positive ones. But the same sensitivity among the Gram negative was observed for all the strains of $P$. aeruginosa and E. coli.

\section{CONCLUSION}

This is the first report of antioxidant activity of alkaloids, flavonoids and methanolic extracts from Euphorbia resinifera L. Besides, this is the first evaluation of antibacterial and antifungal activities of the aqueous extract from the same plant. The results revealed that methanolic extract has a high antioxidant activity followed by flavonoids and alkaloids extracts suggesting the potential of this plant as a natural source of strongly antioxidant substances that can be use as a natural additive in food and pharmaceutical industries. Furthermore, the findings from the present study revealed that the aqueous extract showed a good antifungal activity against all tested microorganisms. In contrast, antibacterial effect was observed only against $E$. coli strain.

\section{REFERENCES}

1. Matkowski A. Plant Phenolic Metabolites as Antioxidants and antimutagens. In: Blume Y, P Smertenko and DJ Durzan (Eds.). In: NATO Life Science Monographs, IOS Press, Amsterdam, Netherlands; 2006. p. 129-148.

2. Lim YY, Lim TT and Tee JJ. Antioxidant properties of several tropical fruits: A comparative study. Food Chem 2007; 103: 1003-1008. http://dx.doi.org/10.1016/j.foodchem.2006.08.038

3. Zulueta A, Esteve M, Frasquet I and Frigola A. Vitamin C, vitamin A, phenolic compounds and total antioxidant capacity of new fruit juice and skim milk mixture beverages marketed in Spain. Food Chem 2007; 103 : 1365-1374. http://dx.doi.org/10.1016/j.foodchem.2006.10.052

4. Campanella L, Bonanni A and Tomassetti M. Determination of the antioxidant capacity of samples of different types of tea, or of beverages based on tea or other herbal products, using a superoxide dismutase biosensor. J Pharm Biomed Anal 2003; 32: 725-736. http://dx.doi. org/10.1016/S0731-7085(03)00180-8

5. Ismail A, Marjan ZM and Foong CW. Total antioxidant activity and phenolic content in selected vegetables. Food Chem 2004; 87: 581-586. http://dx.doi.org/10.1016/j.foodchem.2004.01.010

6. Kafaru E. Immense Help Formative Workshop. In: Essential Pharmacology, Kafaru, E. (Ed.). $1^{\text {st }}$ ed. Elizabeth Kafaru Publishers, Lagos, Nigeria; 1994. p. 11-14.

7. Betoni JEC, Mantovani RP, Barbosa LN, Di Stasi LC and Junior AF. Synergism between plant extract and antimicrobial drugs used on Staphylococcus aureus diseases. Mem. Inst. Oswaldo Cruz 2006; 101: 387-390. http://dx.doi.org/10.1590/S0074-02762006000400007

8. Lewis K and Ausubel FM. Prospects of plant derived anti bacterial. Nat Biotechnol 2006; 24: 1504-1507. http://dx.doi.org/10.1038/nbt12061504 PMid: 17160050

9. Jassbi AR. Chemistry and biological activity of secondary metabolites in Euphorbia from Iran. Phytochem 2006; 67(18): 1977-1984. http://dx.doi.org/10.1016/j.phytochem.2006.06.030 PMid:16889806

10. Huxley A. The New RHS Dictionary of Gardening by Nature Publishing Group, UK; 1992. p. 3000.

11. Kabbaj FZ, Meddah B, Cherrah Y and El Abbes FM. Ethno pharmacological profile of traditional plants used in Morocco by cancer patients as herbal therapeutics. Phytopharmacology 2012; 2: 243-256.

12. Appendino G and Szallasi A. Euphorbium: Modern research on its active principle, resinifera toxin, revives an ancient medicine. Life Sci 1997; 60: 681. http://dx.doi.org/10.1016/S0024-3205(96)00567-X

13. Shi QW, Su XH and Kiyota H. Chemical and Pharmacological Research of the Plants in Genus Euphorbia. Chem Rev 2008; 108: 4295-4327. http://dx.doi.org/10.1021/cr078350s PMid:18817355

14. Villarreal Lozoya JE, Lombardini L and Cisneros Zevallos L. Phytochemical constituents and antioxidant capacity of different pecan Carya illinoinensis (Wangenh.) K Koch cultivars. Food Chem 2007; 102: 1241-1249. http://dx.doi.org/10.1016/j.foodchem.2006.07.024

15. Vaghasiya $\mathrm{Y}$ and Chanda SV. Screening of methanol and acetone extracts of fourteen Indian medicinal plants for antimicrobial activity. Turk J Biol 2007; 31: 243-248.

16. Subramanian SS and Nagarjan S. Flavonoids of the seeds of Crotlaria retusa and C. striata. Curr Sci 1969; 38: 65-68.

17. Muzquiz M. Alkaloids / Gas Chromatography. ID Wilson, ER Adlard, M Cooke, CF Poole (Eds.); Academic Press: New York; 2007. p. 19381949. 
18. Obadoni BO and Ochuko PO. Phytochemical studies and comparative efficacy of the crude extracts of some homeostatic plants in Edo and Delta States of Nigeria. Global J. Pure Appl Sci 2001; 8: 203-208.

19. Sofowora A. Medicinal Plants and Traditional Medicine in Africa. $2^{\text {nd }}$ ed. Spectrum Books Ltd., Ibadan, Nigeria; 1993. PMid:8510470

20. Harborne JB. Phytochemical Methods. $3^{\text {rd }}$ ed., Chapman and Hall, London; 1978. PMid:366554

21. Blois MS. Antioxidant determinations by the use of a stable free radical. Nature 1958; 181: 1199-1200. http://dx.doi.org/10.1038/1811199a0

22. Jothy SL, Zuraini $Z$ and Sasidharan S. Phytochemicals screening, DPPH free radical scavenging and xanthine oxidase inhibitiory activities of Cassia fistula seeds extract. J. Med Plants Res 2011; 5: 1941-1947.

23. Soro S, Ouattara D, Guédé NZ, Coffi K. In vitro and in vivo Inhibitor effect of powder and essential oils extracts of Xylopia Aethiopica (Dunal) A. Rich. (Annonaceae) on Fusarium oxysporum f. sp Radicislycopersici (Forl), parasical fungi of tomatoes cultures. Eur J Sc Res 2010; 39(2): 279-288.

24. Kra KD, Diallo HA, Kouadio YJ. Antifungal activity of Chromolaena odorata (L.) King and Robins extract on two isolates of Fusarium oxysporum (E. F. Sm.) responsible for lethal yellowing of banana leaves. J App Biosc 2009; 24: 1488-1496.

25. Singh P, Kumar A, Dubey NK and Gupta R. Essential Oil of Aegle marmelos as a Safe Plant-Based Antimicrobial against Post harvest Microbial Infestations and Aflatoxin Contamination of Food Commodities. J food sc 2009; 74(6): 302-307. http://dx.doi.org /10.1111/j.1750-3841.2009.01223.x PMid: 19723215

26. Weiss EI, Shalhav M and Fuss Z. Assessment of antibacterial activity of endodontic sealers by a direct contact test. Dent Traumatol 1996; 12 : 179-184. http://dx.doi.org/10.1111/j.1600-9657.1996.tb00511.x

27. Zhang H, Shen Y, Ruse ND and Haapasalo M. Antibacterial activity of endodontic sealers by modified direct contact test against Enterococcus faecalis. J Endod 2009; 35: 1051-1055. http://dx.doi.org/10.1016 /j.joen.2009.04.022 PMid:19567333

28. Rackova L, Majekova M, Kostalova D and Stefek M. Antiradical and antioxidant activities of alkaloids isolated from Mahonia aquifolium. Structural aspects. Bio org Med Chem 2004; 12: 4709-4715. http://dx.doi.org/10.1016/j.bmc.2004.06.035 PMid:15358297

29. Geeta S and Padma K. Evaluation of antimicrobial activity of alkaloids of Terminalia chebula Retz. Against some multidrug-resistant microorganisms. Int $\mathrm{J}$ Green Pharm 2012; 6: 57-62. http://dx. doi.org/10.4103/0973-8258.97131

30. Tim Cushnie TP and Lamb AJ. Antimicrobial activity of flavonoids. Int J Anti microb Agents 2005; 26: 343-356. http://dx.doi.org/10.1016/ j.ijantimicag.2005.09.002

31. Rice Evans CA, Miller NJ and Paganga G. Structure antioxidant activity relationships of flavonoids and phenolic acids. Free Radical Biol Med 1996; 20: 933-956. http://dx.doi.org/10.1016/0891-5849(95)02227-9

32. Khanna VG and $\mathrm{K}$ Kannabiran. Antimicrobial activity of saponin fractions of the leaves of Gymnema sylvestre and Eclipta prostrate. World J Microbiol and Biotech 2008; 24(11): 39-42.

33. Jukie $\mathrm{M}$ and Milos M. Catalytic oxidation and antioxidant properties of the thym essential oils (Thymus vulgareae L.). Croatica Acta 2005; 78: 105-110.

34. Molyneux P. The use of the stable free radical diphenylpicrylhydrazyl (DPPH) for the antioxidant activity. Song Kla nakarin. J Sci Technol 2004; 26(2): 211-219
35. Lee SE, Hwang HJ, Ha JS, Jeong HS and Kim JH. Screening of medicinal plant extracts for antioxidant activity. Life Sci 2003; 73: $167-$ 179. http://dx.doi.org/10.1016/S0024-3205(03)00259-5

36. Brand Williams W, Cuvelier ME and Berset C. Use of a free radical method to evaluate antioxidant activity. Lebensm. Wiss Technol 1995; 28: 25-30. http://dx.doi.org/10.1016/S0023-6438(95)80008-5

37. Hasan SMR, Hossain M, Akter R, Jamila M, Mazumder EH and Rahman S. DPPH free radical scavenging activity of some Bangladeshi medicinal plants. J Med Plants Res 2009; 3(11): 875-879.

38. Popovici C, Saykova I, Tylkowski B. Evaluation of the antioxidant activity of phenolic compounds by free radical DPPH reactivity. Industrial engineering Review 2009; 4: 25-39.

39. Prabu K, Shankarlal S, Natarajan E and Mohamed Sadiq A. Antimicrobial and antioxidant activity of methanolic extract of Eclipta alba. Adv Biol Res 2011; 5: 237-240.

40. Liu X, Zhao M, Wang J, Yang B and Jiang Y. Antioxidant activity of methanolic extract of emblica fruit (Phyllanthus emblica L.) from six regions in China. J Food Compos Anal 2008; 21: 219-228. http://dx.doi.org/10.1016/j.jfca.2007.10.001

41. Baumann J, Wurn G and Bruchlausen FV. Prostaglandin synthetase inhibiting $\mathrm{O}^{-2}$ radical scavenging properties of some flavonoids and related phenolic compounds. Naunyn Schmiedebergs Arch Pharmacol 1979; 307: 1-77.

42. Ryszard A and gnieszka AT. Antioxidant activity of extract of pea and its fractions of low molecular phenolics and tannins. Pol J Food Nutr Sci 2003; 12(53): 10-15.

43. Pilarski R, Zielinski H, Ciesiolka D and Gulewicz K. Antioxidant activity of ethanolic and aqueous extracts of Uncaria tomentosa (Willd.) DC. J Ethnopharmacol 2006; 104: 18-23. http://dx.doi.org/10.1016 j.jep.2005.08.046 PMid:16202551

44. Zhang SJ, Lin YM, Zhou HC, Wei SD, Lin GH and Ye GF. Antioxidant tannins from stem bark and fine root of Casuarina equisetifolia. Molecules 2010; 15: 5658-5670. http://dx.doi.org/10.3390/molecules 15085658 PMid:20714319

45. Sanches ACC, Lopes GC, Nakamura CV, Filho BPD and de Mello JCP. Antioxidant and antifungal activities of extracts and condensed tannins from Stryphnodendron obovatum Benth. Br J Pharm Sci 2005; 41: 101107.

46. Yanxuan $\mathrm{W}$ and Fuhou L. Studies on the antioxidant activities of total alkaloids from the fruits of Evodia rutaecarpa (Juss.) Benth. Adv Mater Res 2012; 396-398: 52-55.

47. Maiza Benabdesselam F, Khentache S, Bougoffa K, Chibane M and Adach S. Antioxidant activities of alkaloid extracts of two Algerian species of Fumaria: Fumaria capreolata and Fumaria bastardii. Rec Nat Prod 2007; 1(2-3): 28-35.

48. Nimri LF, Meqdam MM and Alkofahi A. Antibacterial activity of Jordanian medicinal plants. Pharm Biol 1999; 37: 196-201. http://dx. doi.org/10.1076/phbi.37.3.196.6308

49. Malika N, Mohamed F and Chakib EA. Antimicrobial activities of natural honey from aromatic and medicinal plants on anti bio-resistant strains of bacteria. Int J Agric Biol 2004; 6: 289-293.

\section{Cite this article as:}

Houcine Benmehdi, Nadia Bounoua, Abdelillah Amrouche, Driss Lahcene, Abdelhak Maazouzi. Phytochemical study, antioxidant and antimicrobial activities of Euphorbia resinifera L.Int. Res. J. Pharm. 2013; 4(9):44-50 http://dx.doi.org/10.7897/2230-8407.04910 